\title{
Towards a Study of the 'Famiglia' of the Sforza Court at Pesaro
}

SABINE EICHE

In recent years, scholars of the Italian Renaissance have revived an interest in the social customs of the period, directed towards a better understanding and evaluation of the modes of life of the Renaissance individual. Contemporary biographies, diaries and correspondence, as well as account books and inventories, which already had greatly stimulated the curiosity of our nineteenth- and early twentieth-century predecessors in the field, are once again being assiduously studied and gleaned for insights.

Another potential tool for these investigations has been overlooked more often than not: the structure of a courtly household, the famiglia. ${ }^{1}$ It should be said at this point that the term famiglia was an elastic one in the period under consideration, and that as a result its precise meaning in a given context is not always immediately clear to the modern reader. With reference to a courtly establishment such as that in Milan, Ferrara, Mantua, Urbino, Pesaro, and so forth, the title famiglia describes not only the family and relatives of the lord, but also the attendants, and will be used by me in the sense of all those who served the lord.

The famiglia, then, was composed of staff, who assisted the signore in the running of his state, and of domestics, whose concern was the lord's personal well-being. The size and complexity of a famiglia depended on the political and economic rank of the court, but a basic framework will have been common to most. From the types of famigliari employed we can gain an idea of the administrative policies of the ruler, of his activities and social pretensions. The relationship between the famiglia and the lord was effective in both directions; that is, just as they served him, so he too had certain obligations on their behalf. Therefore, by studying the household, we can also learn something about how the court, in the narrower sense of the palace, functioned as a domestic unit.

The list of famigliari serving at the Pesaro court in the fifteenth century was compiled by me from a variety of sources (see Appendix below). Quite different and more fortunate is the situation in neighbouring Urbino. At the 
beginning of the sixteenth century, a page who had once been in the employ of Federigo da Montefeltro, made a list of the former Duke's famiglia, the names arranged under the headings of the appropriate offices. ${ }^{2}$ Probably not all two hundred members noted by the page were in service at the same time; and the same applies to a chronicler's statement that Lo Ill.o Signor Duca Federico Feltrio Duca d'Urbino... teneva alli serviti sui, bocche No. $800 \ldots{ }^{3}$ The Pesaro list covers an even wider time span than that of Urbino (the Sforza ruled in Pesaro 1445-1512; Federigo was lord of Urbino from 1444-82), and thus cannot reflect the actual structure of the court at any specific moment. It is almost certainly incomplete, since we can expect that documents which I have not yet had the chance to examine will reveal still more names. Nevertheless, for reasons pertaining mainly to the financial and political standing of the court, the Pesaro register, for the period of any one of its Sforza signori, will always be surpassed by that of Urbino.

Names and titles are little more than statistics until we know something about the duties of the famigliari. Once again Urbino enters into the picture, for there survives from the Renaissance an enlightening treatise entitled Ordini et offitij alla corte del Serenissimo Signor Duca d'Urbino.$^{4}$ The author, who remains anonymous although he must have been one of Federigo's court, painstakingly describes the responsibilities of various functionaries, mainly domestic, down to details concerning their personal hygiene. The states of Urbino and Pesaro were structured similarly and were closely linked, not only geographically and politically, but also through inter-marriages, and therefore in an examination of the Sforza court we can safely be guided by some of the instructions written down in the Ordini et offitij of Urbino.

Before embarking on a discussion of the Pesarofamiglia, it will be useful to introduce the court by way of a historical sketch of the town and its rulers. ${ }^{5}$ A port on the Adriatic to the south of Rimini, Pesaro had been a free commune since the late twelfth century. From the late thirteenth until mid-fifteenth centuries, the town was ruled by a branch of the Malatesta family, first in the guise of Podestà, and then as Papal Vicars. In 1445 the inept Galeazzo Malatesta sold the town to Francesco Sforza on the condition that Francesco's brother, Alessandro, just married to Galeazzo's granddaughter, Costanza Varano, be installed as a ruler. The negotiation was in fact highly irregular, since Pesaro was a vicariate of the Church, and it resulted in Pope Eugenius IV excommunicating all parties to the contract. But Alessandro, determined not to relinquish his newly acquired state, persevered and in 1447 Eugenius's successor, Nicholas V, removed the ban and appointed him Papal Vicar.

Alessandro's wife, Costanza, died that same year, leaving him with two children, Battista (future Countess of Urbino) and Costanzo, who were to 
be his only legitimate offspring. In 1448 he married again, choosing Sveva da Montefeltro, half-sister of Federigo, Count of Urbino. The alliance was disastrous and after a few years ended as so many did, with the wife seeking refuge in a convent.

Like his father and brother, Alessandro was a professional soldier, an occupation that denoted long absences from home. While his two consorts were at the court, they could take care of whatever matters, state or otherwise, appeared on the agenda. ${ }^{6}$ By 1457 Sveva had fled, and the responsibility devolved upon Alessandro's son, ably guided during the early years by members of the staff.

Costanzo became Signore of Pesaro after Alessandro died in 1473. Two years later he contracted a brilliant marriage with Camilla d'Aragona, niece of King Ferdinando of Naples. Costanzo outlived his father by only ten years, and, having no legitimate children, was succeeded to the rule by his bastard son, Giovanni. Camilla, by many accounts a wise and charitable stepmother, shared the government of the town with Giovanni until he attained his majority in 1489. In May 1490, when he married Maddalena Gonzaga, Camilla left the court forever, withdrawing to the estate of Torricella, near Parma.

Giovanni married three times, his second union(1493-97) being the illfated one to Lucrezia Borgia. In October of 1500 he temporarily lost his state to his former brother-in-law, Cesare Borgia, but with the assistance of Venice was back in power in 1503. Giovanni ruled without further interruptions until his death in 1510 .

The new Lord was the infant Costanzo II, a son Giovanni had with his third wife, the Venetian Ginevra Tiepolo. According to the terms of his will, Giovanni's natural brother, Galeazzo, was to be appointed regent until Costanzo II was of age. The heir, however, died within two years of his father's demise, after which Galeazzo prepared to assume power in his own name. But Pope Julius II, long interested in Pesaro, bought out Galeazzo, and added the town to the dominions of his nephew, Francesco Maria della Rovere, for whom he had already previously (1504) managed to secure the succession to the Dukedom of Urbino.

By the time Alessandro Sforza ruled the town, the government of Pesaro can be described as a co-operative effort between the commune and the lord. Two councils, the consiglio generale and the consiglio di credenza (of nobles), constituted the main bodies of communal authority. The lord of Pesaro for his part, invested with the rule as Papal Vicar, governed in the name of the Church, at least in theory if not always in deed. However, clear distinction between communal and vicarial/seigneurial power is not in fact possible since the lord, if and when he chose, could have regulated the size, 
and therefore the executive potential, of the two municipal councils. Furthermore, and the situation is not peculiar to Pesaro, an officer of the commune could at the same time have been in the employment of the signore. ${ }^{7}$ Thus it is not surprising to learn that the lord could intervene even in the appointment of municipal servants. ${ }^{8}$

When compared to the organization of the administrative offices of the Duchy of Milan, the relative simplicity of the personnel at Pesaro is clearly indicative of the court's secondary role in the political structure of fifteenth-century Italy. ${ }^{9}$ The staff assisting the ruler of Pesaro in running his state was headed by three ministers: the luogotenente, the segretario or cancelliere, and the referendario. ${ }^{10}$ The auditore, who counselled and had jurisdictional powers, also will have been an important functionary. Appointments do not seem to have been restrictive, for we read in the documents that an individual could serve in more than one high capacity simultaneously; and in at least two instances the Sforza's personal doctor performed ministerial duties: Benedetto Reguardati da Norcia was physician and luogotenente of Alessandro, and Giovanni's doctor, Bernardo Monaldi, was also his segretario, not to mention occasional agent in Venice.

Essentially the signore's principal representative, the luogotenente obviously had to be someone fully in the ruler's confidence. If satisfactory, he held his post for a long time and could survive a change of signori. For instance, the name of Niccolo della Palude is encountered frequently in the documents, first serving Alessandro, then Costanzo. Being one of high rank in the lord's famiglia, the luogotenente was clothed and housed by his employer. ${ }^{11}$ In a debit account of Alessandro's we can read that he had paid two lire, ten soldi, to a shoemaker for Niccolò's boots, and further down in the same list is an entry amounting to twenty lire that he had given for clothes for Niccolò and Angelo (de Probis d'Atri, segretario ?). Niccolò lived in a room iuxta camera domicellarum of the Sforza residence. ${ }^{12}$ Giovanni's luogotenente, Dulcius, still had his quarters in the ruler's palace, but by the time of Guidobaldo della Rovere, in the mid-sixteenth century, the Duke's luogotenente was assigned rooms in the newly constructed Palazzo Comunale. ${ }^{13}$

Cancellieri, and the segretario, a superior cancelliere, handled correspondence and related matters. As the Urbino Ordini et offitij tells us, such officers should be pochi, pratichi, boni, sufficienti et fidelissimi quanto piu se possesse dire. The segretario kept the seal, which could also be delegated to a trusted cancelliere. Letters sent from the court did not leave without being checked by him, and he kept and filed incoming correspondence per modo che omne una, per minima, bisognando se retrovasse. ${ }^{14}$ Giovanni, in his will, echoes some of these recommendations: Item voglio, che tutte le expeditioni importante del Stato, passino 
per mano de' Turricella (his segretario/cancelliere), et che sotto lui se toglia uno Cancelliero per le expeditioni occorenti, le qual tutte si habbiano ad expedire secondo l'ordine et commissione di mio Fratello (Galeazzo). ${ }^{15}$

The referendario (sometimes called revisore), third of the three top state officials, administered the finances. ${ }^{16}$ Helping him and the cancellieri in the execution of their duties were the computista, cassiero, avvocato fiscale, scrittore, depositario, tesoriere, and maestro delle entrate.

Many of the officials engaged in state affairs had their working quarters in the palace. The cancelleria of the Pesaro court initially was located on the ground floor of the Sforza palace, near the entrance portico. By the early sixteenth century it had been moved to the upper storey of the residence, although still in the front wing, into the former music room. Near the ground floor cancelleria was the audientia of the referendario. It was most efficient to have the offices of the staff concentrated in one part of the palace, but the Pesaro residence, unlike that of Federigo da Montefeltro, was not built anew with few restrictions, and thus never achieved the ideal organization of spaces prescribed by Renaissance architectural theorists. In fact, documents reveal that in the 1450's the room of the computista, at that time the Florentine Giovanni Battista dell'Antella, was in the rear wing of the residence, on an upper floor, close to the private apartment of the young Costanzo Sforza. ${ }^{17}$

A courtly staff was not limited to internal functionaries; important roles were played also by the oratori, or ambassadors, in foreign centres. They served primarily as diplomats and informers. We know that Alessandro had a man, Roberto Ondedei, in Venice; Costanzo sent Domenico di Barignano and Giacomo Probo d'Atria to Rome as oratori; Giovanni as well kept ambassadors at those two courts, and also in Milan. Like the luogotenente, the ambassadors were men of the utmost confidence, so that when they served well, they served long. Or, as Giovanni phrased it in his will: Item si mantenga sempre un' Ambasciadore residente in Roma il quale per essere stato fedele, et haver diligentemente servito, non mi pare, se habbia ad mutare. ${ }^{18}$

Before turning from state to domestic officials, reference should be made to the Sforza's other occupation as mercenary soldiers. It was a profession that in time of war required the maintenance of a large retinue of men-atarms. When Alessandro was hired by the Venetian Republic in 1467, it is said that his contract stipulated 600 calvary and 2,000 infantry. ${ }^{19}$ Top officers were chosen from among the Sforza intimates. Costanzo, for instance, selected as two of his capi di squadra or squadreri, Niccolo di Barignano, his segretario, and Raniero Almerici, equitis, who in 1468 had been created Count Palatine, probably at the urging of Alessandro.

The Sforza court employed a large body of personnel, whose tasks ran 
from the purely banal to the intellectual and spiritual. Household chores, for example the putting in order of rooms in the morning, were carried out by massari, as we can read in a letter of 1457 reporting on a domestic crisis. ${ }^{20}$ Their status cannot have been too low, however, for as is written in another letter of 1458 directed by Pier Sante da Sarnano to the Duchess of Milan, the twelve-year-old Battista during her father's absence from the court was attended by numerous ladies-in-waiting and massare da bene. ${ }^{21}$

A variety of servants were occupied with the preparation and serving of food at court. The Urbino Ordini et offitij recommended separate cooks for the famiglia, the guests, and the lord. We cannot be certain that the Sforza followed the prescribed arrangement since the documents found to date are virtually silent on this aspect of daily life at the court. The name of only one cook, Giovanni di Pietro alias Riccio del fu Scaramuccia di Torricella parmense, serving in 1493, has come to light. The only other information we have is that the kitchens in the Sforza residence were located below ground level. ${ }^{22}$ To inspect these quarters in the morning and at night was the duty of the scalco or siniscalco, who had to ensure that the lord was served according to his tastes. All matters pertaining to the lord's table were his responsibility. The scalco was rated superior to all other servants, with the exception of the maestro di casa, ragioniere, and fattore generale, this latter in charge of the numerous country estates. ${ }^{23}$ Revealing for the confidential position of the scalco is a remark by the above mentioned Pier Sante in the same letter of 1458: for the six-month period when Alessandro was away on a mission to France and the Netherlands, Marco Monaldi, his scalco, was the one who had la cura principale de Constantio ad ogni ora. Benedetto Reguardati da Norcia confirms this when he writes, likewise in a letter of 1458 to the Duchess of Milan: Per suo (Costanzo's) guberno sta Marco Monaldi scalco. ${ }^{24}$ The eleven-year-old Costanzo at the same time had his own personal scalco, Francesco de maestro Angelo.

Assisting the scalco at the table was the credenziere, who saw to it that the silver and table linens were impeccably clean. He furthermore had to guard the silver and other precious things consigned to his care by the maestro di casa, scalco and maestro di guardaroba. In view of his extra duty as watchman, it was suggested that he live in a conveniently located room in the palace. ${ }^{25}$

A splendid picture of the ritual at table can be gained from the description of Costanzo's wedding celebrations in 1475. At the banquet, two siniscalchi, in this case the young relatives Carlo Sforza and Ercole Bentivoglio, were deputed to the head table. Each carried a golden baton to mark his elevated status among the attendants, and brought to the seated guests a golden basket filled with cutlery and napkins. Thirty garzoni and servitori helped the siniscalchi to wait. ${ }^{26}$ 
On the occasion of such great feasts, and at times also for more ordinary events, musicians, singers and dancers would entertain. Costanzo's wedding meal was enlivened by pifferi, trombetti, tamburini, an organist and thirty-six singers. ${ }^{27}$ History has remembered the names of only two fifteenth-century ballerini at the court of Pesaro. Guglielmo ebreo was choreographer of the dances at Alessandro's wedding in December 1444, and later in 1463 he dedicated a dance treatise to Galeazzo Maria Sforza of Milan. The services rendered at Pesaro by the second ballerino, Giovanni Ambrogio, are not known, although a treatise by him figures in the Sforza library inventory drawn up in 1500 . A letter written in 1466 by Giovanni Ambrogio reveals that shortly before that date he had come from the court of Milan to that of Naples to instruct the young Eleonora d'Aragona alo ballare lombardi. ${ }^{28}$

Valet of the signore was the cameriere maggiore, assisting him to dress and undress, and ascertaining that everything in the lord's room was to his satisfaction. Should the signore decide to wear jewels, the cameriere maggiore was held responsible for their safety until they were restored to their place in the guardaroba. ${ }^{29}$

The Urbino Ordini et offitij laid great stress on cleanliness and hygienics, and one of the people engaged to maintain the desired standard at court was the barbiere. Whereas the barber of the famiglia was required to be able to pull teeth and treat cirrhosis, the personal barber of the lord, uno giovene pulito, discreto, concerned himself with washing the hair of the pages, or of anyone else sent to him by the signore. He had to make sure that the cloths designated for use by the lord were kept white and clean, and the razors and other instruments in good working order. It was recommended that he have a shop in the palace, and in the case of Alessandro we know that his barbiere was assigned a room on the courtyard of the residence. ${ }^{30}$

The maggiordomo, or maestro di casa, oversaw the entire domestic staff. Representing the authority of his master, he had to ensure that all the lord's orders were carried out. Accordingly, he was to be given a room in the palace in honorato loco, dove el discorso de tucto sia facillissimo. ${ }^{31}$

Administering to the religious needs at court was the cappellano. We learn from the letter of Pier Sante, describing the situation at Pesaro during Alessandro's extended absence, that the young Battista and Costanzo had el capellano che ogni di gli dice messa in casa. ${ }^{32}$ When necessary the chaplain could also act as confessor. Regarding Alessandro, this service would not have been required after 1470 because on 29 May of that year he had been granted a Bolla con uno breve apostolica de possere hautre dui confessori religiosi apresso se. ${ }^{33}$ The cappellano was furthermore instructed to give the maestro di casa and the scalco two days notice of tucte le vigilie comandate et quatro tempore et quaresima. ${ }^{34}$ 
An essential member of the famiglia was the humanist tutor. Instead of sending his children to be educated at a foreign court, such as that of Ferrara where he himself as a young boy had attended classes, Alessandro hired grammar masters to instruct Battista and Costanzo at home. One of these was Matteo da Sassoferrato, father of the famous Pandolfo Collenuccio. Perhaps Matteo, also trained as a notary and cancelliere, did not possess all the humanistic skills desired by Alessandro, since in 1459 when the children had reached the ages of twelve and thirteen he replaced him with the more illustrious Martino Filetico, pupil of Guarino Guarini.

Like the Montefeltro, the Sforza of Pesaro owned a notable collection of manuscripts and employed a librarian to take care of them. Vespasiano da Bisticci, in his biography of Alessandro, wrote that he had uno uomo dotissimo con buona provisione sopra questa libreria.$^{35}$ It is the only mention I have found to date of the Sforza librarian, and not even his name is known to us. A chapter in the Ordini et offitij outlining the librarian's responsibilities can also serve to shed light on the Sforza man's daily routine. Besides keeping an inventory of all the manuscripts, and a record of those lent out, the bibliotecario was required to shelve the works according to an orderly system so that any manuscript would always be easy to locate. He should endeavour to prevent thefts, of which there was always the danger when many people (multitudine) thronged in the library. The manuscripts were to be guarded from the silly, the ignorant, the filthy and the disgusting. Care was to be taken that no one creased pages or turned back to the same page too often, et, quando se mustrano a persona ignorante che per curiosità li volesse vedere, se non è di troppo auctorità, basta una ochiata. ${ }^{36}$

Federigo da Montefeltro maintained a team of scribes and illuminators, but there is no evidence that Alessandro did the same. Probably he had to content himself with commissioning artists at foreign courts to produce the manuscripts for him. It is not until the time of Costanzo that we encounter the name of a copista at court, and it is still unclear if he was alone or part of a workshop. ${ }^{37}$

Housing Federigo's library in the palace at Urbino was a room of modest dimensions, located at ground level between the entrance vestibule and the stairs to the upper storey. ${ }^{38}$ Also Alessandro built a library in his town palace, but it does not survive and once again Vespasiano's words remain the only reference to its appearance: . . fece fare uno degnissimo luogo nel suo palagio con armarii intorno dove erano per ordine tutti quegli libri ${ }^{39}$ Further evidence for concluding that the design and organization of the Sforza library must have been admirable is provided by a letter that Vespasiano addressed to Alessandro, requesting his highlyvalued opinion on a new arrangement of the Medici library. ${ }^{40}$ We cannot be absolutely sure of the room's location in the Sforza palace, but I have 
proposed elsewhere, on the basis of a late fifteenth-century document, that already from the time of Alessandro the library had been one of the rooms overlooking the garden near S.Agata. ${ }^{41}$

Another part of the famiglia was occupied with construction and repair work at the court. Under the heading of Ingegneri, et Architetti the Urbino list proudly includes Luciano da Laurana and Francesco di Giorgio, two names difficult to surpass in the 1460's and 1470's. ${ }^{42}$ Although Alessandro sometimes requested Laurana's intervention in building projects at Pesaro, he never engaged him as court architect. ${ }^{43}$ The situation changed with Alessandro's son. From 1476 until his death in 1479, Laurana, who by then had left Urbino, figures in the documents as the engineer of Costanzo Sforza. It is to him that the design of the Rocca Costanza is attributed, the most important construction underway in Pesaro during those years. Cherubino di Milano was another of Costanzo's engineers, and he continued to work for Giovanni. A document of 1492 describes him as the superintendent of all work on fortifications, bridges, roads, dams, etc.

Finally, a word can be said about the recruitment of individuals for the household. In at least two instances, that of Francesco Becci and that of Marco Citara, we know that the servants had been merchants prior to their employment at court. Although to us such social mobility may suggest an enlightened tolerance, the procedure could have been simply the most expedient way of satisfying a need. The names of the famigliari at the Sforza court reveal that often members of the same family continued to serve for more than one generation, or that more than one individual of the same generation was engaged. In this regard, the most prominent family was that of the Almerici, who could boast at least six famigliari at the court, and who remained one of the most important aristocratic families of the town long after the Sforza had died out.

The purpose of this essay has been twofold. On the one hand, I have tried to indicate the usefulness of studying the organization of a noble household, in the hope of encouraging similar examinations for other Italian courts. Furthermore, with the focus on Pesaro, I have wanted to begin to remove some of the obscurity that shrouds so many aspects of Renaissance life in that town, and to stimulate the search for more documents which would broaden and clarify our picture of the Sforza court.

Kunsthistorisches Institut, Florence 
Notes

1 Cardinal's famiglie, on the other hand, have received considerable attention; see, for instance, $\mathbf{A}$. Paravicini Bagliani, Cardinali di Curia e "Familiae" cardinalizie ... 1227-54, 2 vols., Padua 1972, especially pp.443-516; N. Zacour, "Papal Regulations of Cardinals' Households in the Fourteenth Century," Speculum, (1975), pp. 434-55; K. Weil-Garris and J.F. D'Amico, The Renaissance Cardinal's Ideal Palace: A Chapter from Cortesi's De Cardinalatu, Rome, 1980; D'Amico, Renaisance Humanism in Papal Rome, Baltimore, 1983, pp.38ff. An examination of a royal household, but primarily from the administrational point of view is included by $A$. Ryder, The Kingdom of Naples under Alfonso the Magnanimous, Oxford, 1976, pp.54-90. Some stirrings of interest in the functions of a Renaissance courtly household can be found in W. Gundersheimer, Ferrara, Princeton, 1973, pp.51ff, 285-96. An excellent and stimulating account of noble households, but in England rather than Italy, is in M. Girouard, Life in the English Country House, New Haven, 1978.

2 Vatican Library cod. Urb. lat. 1204,Memoria felicissima dell'illustrissimo signor duca Federico e della sua famiglia che tenea, cc.97v ff. The author is Susech of Casteldurante. G. Zannoni published it, but not without mistakes, in Scrittori cortegiani dei Montefeltro, Rome 1894, pp.8085; the errors are corrected by L. Venturi in "Studi sul Palazzo Ducale," L'Arte vol. 17, 1914, pp. 470-71. Also G. Ermini printed it, as the Appendix to his publication of the Vatican Library cod. Urb. lat. 1248, Ordini et offitij alla corte del Serenissimo Signor Duca d'Urbino, Urbino 1932. See also C.H. Clough, "Federigo da Montefeltro's Patronage of the Arts, 1468-82," Journal of the Warburg and Courtauld Institutes vol.36, 1973, pp. 131-32 and n.17. At the Convegno di studi su Federico da Montefeltro, Urbino 3-8 October 1982, P. Peruzzi delivered a paper entitled "Ordine et officij: lavorare a Corte," stressing the political significance of the household. A list of court officials exists also for Ferrara in the fifteenth century, contained in the chronicle of Ugo Caleffini, Vatican Library cod. Chig. I.I.4; see Gundersheimer, Ferrara, pp.285ff.

3 Clough, "Federigo," pp.131-32. The chronicle is published by G. Baccini, "Ristretto di fatti d'Italia e specialmente d'Urbino dal 1404 al 1444," Zibaldone, Florence 1888, p.93.

4 See n. 2 above. All my references to the Ordini et offitij will be to the Ermini edition.

5 For what follows see my dissertation, Alessandro Sforza and Pesaro: A Study in Urbanism and Architectural Patronage, Princeton 1982.

6 See for instance Pesaro, Biblioteca Oliveriana (hereafter Bibl.Oliv.) 455,vol.1, cc.129-31: Supplica di Nofria moglie del fu Niccolo delli Balignani (sic.) da Pesaro a Costanza, moglie di Alessandro Sforza, che governava in assenza del marito a Roma (22 March 1447); c.190: Ordine di Sveva Sforza, in assenza del marito Alessandro, al Conte Vano dei Bonifazi da Sarnano, Podestà di Pesaro per l'appello d'una causa che verteva tra Bonaccursio di Pietro de' Monaldi e Madonna Raffaella figlia di Giovanni di Oddo di Taddeo delli Ranieri (22 April 1450); c.326: Madonna Sveva, moglie d'Alessandro Sforza, sottoscrive una supplica del Dottore Antonio Silvestri per alcuni beni comprati da forestieri (2 January 1455); 455, vol.II, cc.153-63: La Contessa Sveva dispensa della guardia per l'età Pietro Buxio (22 May 1456).

7 Clough, "Sources for the Economic History of the Duchy of Urbino, 1474-1508," Manuscripta vol.10, 1966, p.9; Gundersheimer, Ferrara, p.292.

8 For instance, on 9 December 1488, Giovanni and Camilla nominated Vincenzo de' Fedeli di Pesaro and Alberto Alberti as the Ufficiali dei Pupilli; see Bibl.Oliv. 376, vol.VI, c.422. On 8 March 1496 Giovanni appointed Pier Matteo Giordani as Ufficiale dei danni, reconfirmed in 1498, 1499, and 1503; see Bibl.Oliv. 376, vol.IX, cc.136-37.

9 For Milan see the excellent modern study by C. Santoro, Gli uffici del dominio sforzesco (14501500), Milan 1948, especially the introduction, pp.xv-xxxiii, where she defines the duties of the various officers. Also useful here is G. Rezasco, Dizionario del linguaggio italiano storico ed amministrativo, Florence 1881, rpt. Bologna 1966.

10 B. Feliciangeli, Sull'acquisto di Pesaro fatto da Cesare Borgia, Camerino 1900, p.53 n.2.

11 See the Ordini et offitij, pp.36, 37-39.

12 The accounts page is published in my dissertation (see n.5), pp.478-79; for the reference to Niccolo's room in the palace see my dissertation, p.483, docs. 17, 18. 
13 For Dulcius see my dissertation, p.496 doc.70, p.497 doc.73, p.498, doc.76. For the Duke's luogotenente see G. Vaccai, Pesaro, Pesaro 1909, p.123.

14 Ordini et offitij, pp.76-80. The cancellieri and segreterio should be "few in number, capable, superior and as faithful as possible;" the segretario filed the letters "systematically so that they could always be easily found again."

15 "I want Turricella to be in charge of all important correspondence pertaining to the affairs of state, and he should have a cancelliere to help him, and everything must be carried out according to the orders of my brother." Giovanni's testament will be fully transcribed by me in a forthcoming study.

16 But cf. Gundersheimer, Ferrara, p.56: the referendarius served as head of the cancelleria. Giovanni's will makes it clear that in Pesaro he was in charge of the accounts: Item che 'I faccia rivedere tutti i conti vecchi da qui in dreto, et chi hà ad dare dia, et chi hà ad havere sia soddisfatto, talmente che ogni uno habbia il suo credito, et se 'I non si potesse cosi al presente, satisfacciati quando si potrà, purche una volta sieno contenti, et ch'el se striga tutti li conti vecchi, et ad questo sarà buono Marco Cithera (his referendario and maestro delle entrate) per essere instrutto.

17 See my dissertation, pp. $166,171,480-81$ doc.5, 487 doc. 31,490 docs. $44,46,491$ doc.50, 492 doc.51, 493-94 doc.59.

18 "There should always be a resident ambassador in Rome, and if he is faithful and serves diligently, it is not necessary to replace him."

19 G. Soranzo, Cronaca di Anonimo Veronese 1446-1488, Monumenti di Storia Patria, ser.3. Cronache e diarii, vol.IV, Venice 1915, p.243. A very useful study, explaining condottieri's contracts, is that by M. Mallett, "Venice and its Condottieri, 1404-54," in Renaissance Venice, ed. Hale, London 1973, pp.121-45.

20 A. Madiai, "Nuovi documenti su Sveva Montefeltro Sforza," Le Marche vol.IX, 1909, p.111. But cf. Ordini et offitij, pp.58-59, on the massaro.

21 Feliciangeli, Alcuni documenti relativi all'adolescenza di Battista e Costanzo Sforza, Turin 1903, p.9.

21 Ordini et offitij, pp.51-54; for the Pesaro kitchens see my dissertation, p.167.

23 Ordini et offitij, pp.3-6, 54-57.

24 Feliciangeli, Battista, pp.10, 13.

25 Ordini et offitij, pp.10-11.

26 M. Tabarrini, Descrizione del convito e delle feste fatte in Pesaro, Florence 1870, p.14.

27 Tabarrini, Descrizione, pp.11, 12, 13, 37; see also Ordini et offitij, pp.64-65. Interesting in this connection is an article by M. Mamini, "Documenti quattrocenteschi di vita musicale alle Corti Feltresca e Malatestiana," Studi Urbinati n.s.B, anno XLVIII, 1974, pp.115-28.

28 Guglielmo's treatise is in the Bibliotheque Nationale of Paris, cod. ital. 973; see G. Mazzatinti, Inventario dei manoscritti italiani delle biblioteche di Francia, vol.I, Rome 1886, p.172. On Guglielmo see also E. Motta, "Musica alla corte degli Sforza," Archivio Storico Lombardo ser.2, vol.IV, anno XIV, 1887, pp.62-63 n.2; E. Rodocanachi, La Femme Italienne à l'Epoque de la Renaissance, Paris 1907, p.198; F. Malaguzzi Valeri, La corte di Lodovico il Moro, vol.I, Milan 1913, p.539; Arte lombarda dei Visconti agli Sforza, exhibition catalogue, Milan 1958, p.89 no.271; E. Pellegrin, La Bibliothèque des Visconti et des Sforza, Supplement, Florence 1969, pp.40-41. The inventory of the Sforza library is in Bibl.Oliv. 387, see on c. 36 the work entitled Io. Ambrosio ballarino. A. Vernarecci has published the inventory: "La libreria di Giovanni Sforza," Archivio Storico per l'Umbria e le Marche vol.III, 1886, see p.518. A treatise by Giovanni Ambrogio is in the Bibliotheque Nationale, Paris, cod. ital. 476; see Mazzatinti, Inventario, p.98. The letter by Giovanni Ambrogio is published by Motta, "Musica," pp.61-62; see also Storia di Milano, vol.IX, Milan 1961, p.814.

29 Ordini et offitij,pp.16-19. See also Susech's comment on the Cambrieri del Duca (as published by Zannoni, Scrittori, p.82): per tenere a ordine le camere e le sale et ad invitare le donne per le feste.

30 For a discussion of the principles of sanitation and neatness to be observed, see especially pp. 20 22 of the Ordini et offitij; for the barber, pp.22-23. Regarding the location of the room in Alessandro's palace, see my dissertation, p.481 doc.7. 
31 Ordini et offitij, pp.1-3. The maestro di casa should be given a room "in an honourable place, where it will be easy to discuss all matters."

32 Feliciangeli, Battista, p.10. The children had "the chaplain who says the mass for them at home every day."

33 "Bull with an apostolic brief allowing him to have two personal religious confessors." See the inventory of Alessandro's private papers in Bibl.Oliv. 441, c.20, but without the year; the date is given in Bibl.Oliv. 376, vol.VII, c.84.

34 Ordini et offitij, pp.63-64. The chaplain had to remind them of "all the fast-days ordered by the Church, the Ember Days, and Lent."

35 Le vite, ed. A. Greco, vol.I, Florence 1970, p.423: "a most learned man, well paid, who is in charge of this library."

36 Ordini et offitij, pp.75-76. And when the librarian "shows a manuscript to someone ignorant who wants to see it out of curiosity, if he is not an important person a quick glance will do."

37 See my dissertation, p.142.

38 After having been closed for many years, and subsequent to a thorough restoration, the library was re-opened to the public on the occasion of the Convegno di studi su Federico da Montefeltro. P. Dal Poggetto gave a paper discussing this among other restorations: "Nuove letture di ambienti e opere d'arte federiciane: la Biblioteca, il Bagno della Duchessa, la Neviera." See also Clough, "The library of the Dukes of Urbino," Librarium vol.IX, 1966, pp.101-104.

39 Le vite, p.423: "he had a noble room built in his palace, with shelves all along the walls on which the books were set in a well-ordered fashion."

40 A. Cagni, Vespasiano da Bisticci e il suo epistolario, Rome 1969, p.159.

41 See my dissertation, pp.179-81.

42 Zannoni, Scrittori, p.82; Ordini et offitij, Appendix p.v.

43 See my dissertation, pp.190-94.

\section{APPENDIX: The Sforza 'famiglia'}

\section{Abbreviations:}

ASF: Archivio di Stato of Florence

ASPN: Archivio di Stato of Pesaro (Notarile)

Bibl.Oliv.: Biblioteca Oliveriana, Pesaro

Cinelli: C. Cinelli, Pandolfo Collenuccio, Pesaro 1880

Feliciangeli, Battista: B. Feliciangeli, Alcuni documenti relativi all'adolescenza di Battista e Costanzo Sforza, Turin 1903

Costanza: Notizie sulla vita e sugli scritti di Costanza Varano Sforza, Turin n.d. Elisabetta: Notizie della vita di Elisabetta Malatesta Varano, Ascoli Piceno 1911 , L'itinerario: "L'itinerario d'Isabella d'Este Gonzaga attraverso la Marca e l'Umbria nell, aprile del 1494," Atti e Memorie della Deputazione di Storia Patria perle Marche n.s. vol.VIII, 1912, pp.1-119.

, Lettere: Lettere di Galeazzo Sforza al fratello Giovanni signore di Pesaro ottobre novembre MDII, Sanseverino-Marche 1915.

Lucrezia: Il matrimonio di Lucrezia Borgia, Turin 1901

Sull'acquisto: Sull'acquisto di Pesaro fatto da Cesare Borgia, Camerino 1900

Sveva: Sulla monacazione di Sveva Montefeltro, Pistoia 1903

Gregorovius: F. Gregorovius, Lucrezia Borgia, Stuttgart 1874

Madiai: A. Madiai, "Nuovi documenti su Sveva Montefeltro Sforza," Le Marche IX, 1909, pp.94-142.

Miniature: Vatican City, Biblioteca Apostolica Vaticana, Miniature del Rinascimento, exhibition catalogue 1950 
Olivieri, Appendice: A. Olivieri, Appendice alle memorie di Alessandro Sforza, Pesaro 1786 , Diplovatazio: Memorie di Tommaso Diplovatazio, Pesaro 1771

, Gradara: Memorie di Gradara, Pesaro 1775

, Lettera: Lettera sopra un medaglione non ancor osservato, Pesaro 1781.

, Michelina: Della patria della B. Michelina e del B. Cecco, Pesaro 1772

,S. Tommaso: Memorie della badia di S. Tommaso in Foglia, Pesaro 1778

, Sforza: Memorie di Alessandro Sforza, Pesaro 1785

,Zecca: Della zecca di Pesaro e delle monete pesaresi dei secoli bassi in G.A. Zanetti, Nuova accolta delle monete e zecche d'Italia, vol.I, Bologna 1775, pp.179-246.

Paltroni: P. Paltroni, Commentari della vita et gesti dell'illustrissimo Federico Duca d'Urbino, ed. W. Tommasoli, Urbino 1966

Pellegrin: E. Pellegrin, La Bibliothèque des Visconti et des Sforza, Supplement, Florence 1969

Ratti: N. Ratti, Della famiglia Sforze, vol.I, Rome 1794

Rodocanachi: E. Rodocanachi, La Femme Italienne à l'Epoque de la Renaissance, Paris 1907.

Sajanello: G.B. Sajanello, Historica Monumenta Ordinis Sancti Hieronymi Congregationis B. Petri de Pisis, vol.II, 2nd ed., Rome 1760

Saviotti: A. Saviotti, "Giacomo da Pesaro," Archivio Storico per l'Umbria e le Marche IV, 1888, pp.73-81.

Soranzo, Anonimo: G. Soranzo, Cronaca di Anonimo Veronese 1446-1488, Monumenti di Storia Patria, ser.3, Cronache e Diarii, vol.IV, Venice 1915

Soranzo, Cronaca sconosciuta: "Di una cronaca sconosciuta del secolo XV e del suo anonimo autore," Nuovo Archivio Veneto XIII, 1907, pp.68-103

Tabarrini: M. Tabarrini, Descrizione del convito e delle feste fatte in Pesaro, Florence 1870

Vaccai, Ginevra: G. Vaccai, "Il quadro votivo di Ginevra Tiepolo," Rassegna Marchigiana VII, 1928-29, pp.167-72

\section{pp.28-37}

,Le nozze: "Le nozze di Costanzo Sforza con Camilla di Aragona," Picenum XIX, 1922,

,Le ville: "Le ville del monte Accio e la societa pesarese nel secolo XVI," Picenum XVIII, 1921, pp.260-68.

1909: Pesaro, Pesaro 1909

1928: La vita municipale sotto i Malatesta, gli Sforza e i Della Rovere, Signori di Pesaro, Pesaro 1928

Vernarecci, L'incendio: A. Vernarecci, "L'incendio della libreria di Giovanni Sforza," Archivio Storico per l'Umbria e le Marche III, 1886, pp.790-92.

, La libreria: "La libreria di Giovanni Sforza," Archivio Storico per l'Umbria e le Marche III, 1886, pp.501-23

\section{Glossary}

Allevato: one raised at the court

Armigero (Uomo d'arme): man-at-arms

Auditore: a counsellor with jurisdictional powers

Avvocato fiscale: magistrate of the revenue

Balestriero: crossbowman

Ballerino: dancer

Barbiere: barber

Bibliotecario: librarian

Cameriere maggiore: head manservant, valet Cancelliere: chancellor
Cappellano: chaplain

Cassiero: treasurer

Castellano: commander of the fortress

Cavaliere: knight

Commensale: one who ate at the lord's table

Commissario: commissary

Computista: accountant

Connestabile: constable in command of the town gates

Consigliere: counsellor

Consultore: counsellor 


\section{2 / Renaissance and Reformation}

Copista: scribe

Corriere: messenger

Credenziere: head servant overseeing the table; originally one who tasted all the food to be served to the lord

Curiale: courtier

Damigella (Domicella, Donna di compagnia): lady-in-waiting

Depositario: treasurer

Dispensiere: steward of the household

Equitis: knight

Fattore generale: steward of the estates

Fornaio: baker

Forniciaro: one who bakes bricks, etc.

Garzone: young servant

Giureconsulto: jurisconsult

Luogotenente: lieutenant

Maestro di casa (Maggiordomo): majordomo

Maestro delle entrate: master of the revenue

Maestro di guardaroba: master of the wardrobe

Maestro di stalla: head of the stables

Marescalco: farrier

Massaro: domestic steward

Muratore: brick-layer
Notaio: notary

Oratore: ambassador

Procuratore: procurator, agent

Piffero: piper

Ragioniere: accountant

Rappresentante: delegate, representative

Referendario (Revisore): comptroller

Sagitarrio: archer

Scalco (Sescalco, Siniscalco): head servant overseeing the meals; originally denoted a carver

Scrittore: official writer

Scudiero: equerry

Segretario: secretary

Sopraintendente: superintendent

Soprastante: overseer, usually of construction work

Squadrero (Capo di squadra): leader of troops

Staffiere: messenger

Tamburino: drummer

Tesoriere: treasurer

Trombetto: trumpeter

Vicario delle gabelle e delle appellazioni: officer in charge of taxes and appeals

Famigliari:

N.b. The order is alphabetical by first name. Included are members of the Malatesta court at Pesaro who continued to work for the Sforza. The dates given are those found in the documents. Where there is more than one year per entry, the archival and bibliographical references are arranged chronologically according to these dates.

Alberto Albergati da Bologna

1503

procuratore for Giovanni Sforza, to borrow money for the restitution of the Rocca Costanza Feliciangeli, Lettere, p.41 n,20

Alessandro di Matteo dei Collenucci di Pesaro 1489,1493

capitano of Montelevecchie

Bibl.Oliv. 376, vol.VI,cc.421, 418

Alessandro Pugliano (Pogliano) de Interamna (Introcinis, Introcinio) de Benevento (Rieti) 1464

famigliare of Alessandro Sforza

Bibl.Oliv. 376, vol.I, cc.440v-441; Sajanello, p.377; Olivieri, Sforza, p.LXXXIV

\section{Almerico Almerici}

1464, 1470, 1490; died 1492

vicario delle gabelle e delle appellazioni for Alessandro; podestà of Pesaro; avvocato fiscale della camera for Giovanni

Bibl.Oliv. 376, vol.II, cc.630v-631; Bibl.Oliv. 376, vol.I, c.442v; Bibl.Oliv. 376, vol.VI, c.412; Olivieri, Diplovatazio, p.XI

\section{Almoro Brandolin da Mestre 1500}

oratore for Giovanni in Venice

Feliciangeli, Sull'acquisto, pp.31-92, 32 n.1

Alo, detto Battaglino del fu Ranaldo di Arquata 1457

servo of Alessandro

Bibl.Oliv. 376, vol.II, c.396 
Alovisio (Aloisi, Luigi) Basicaretri 1457

credenziere and dispensiere of Alessandro

Feliciangeli, Sveva, p.56; Madiai, pp.95,97

Mro Andrea di Girolamo de S. Angelo

1509; dead by 1512

ingegnere of Giovanni

Bibl.Oliv. 455, vol.II, c.139v; ASPN, Domenico Zucchella, vol.47, 2 April 1512, page unnumbered

Angelo de Probis d'Atri

1457, c. 1463,1467

segretario, cancelliere, famigliare of Alessandro Olivieri, Michelina, p.LIX; idem., Sforza, p.LXXIII; Madiai, p.96; Soranzo, Anonimo, p. 243 n. 1

Antonello del fu Matteo Panzano

1491

curiale of Giovanni

Bibl.Oliv. 376, vol.VI, c.370

Antonello Picinino

1458

one of the servants named as having the care of Battista Sforza during Alessandro's absence 1457-58

Feliciangeli, Battista, pp.10,12

Antonello da Tortona

1492

siniscalco of Giovanni

Bibl.Oliv. 455, vol.II, c.17

Ms Antonio

Barbiere of Giovanni

Cinelli, p.57

Ser Antonio de l'abbate (family came from Brescia to Pesaro in 1393)

1458; died 1478

cancelliere of Costanza Sforza, then served Alessandro and Costanzo; named as having the care of Battista during Alessandro's absence $1457-58$

Feliciangeli, Battista, p. 10

Antonio dalla Badia

1493

balestriero of Giovanni

Bibl.Oliv. 455, vol.II, c.106
Antonio da Brescia (same as Ser Antonio de l'abbate ?)

c. $1457,1460 \mathrm{~s}$

cameriere, cameriere scalco of Alessandro

Madiai, pp.94, 97; Bibl.Oliv. 374, vol.I, c.57-

$57 \mathrm{v}$

Antonio Ferrarese di Francesco Forzate 1457

allevato of Alessandro (he carried letters back and forth between Alessandro and his mistress)

Feliciangeli, Sveva, p.17; Madiai, p.112

Antonio di Gaspare gia di Montecicardo 1498

capitano of Monte Gaudio

Bibl.Oliv. 376, vol.VI, c.425

Ser Antonio de Strullis da Coldazzo

1430s; died c. 1460

grammar instructor to Costanza Varano

Feliciangeli, Battista, p.6; idem., Costanza, p.17 note

Arcangelo Ayberti (d'Ayberto da Trevi) scalco of Giovanni

Feliciangeli, Lucrezia, p.78; idem., Sull'acquisto, p.47 no.3, p.72 n.1

Ser Baldo del fu Paolo di Urbino

1486

maggiordomo of Camilla and Giovanni

Bibl.Oliv. 376, vol.VI, c.383v

Bartolommeo dei Cavaliere da Ferrara

1493

Giovanni's oratore at the court of Milan

Feliciangeli, Lucrezia, p.32 n.1

Mro Bartolomeo di Zanno da Vigevano (M. Bartolo Janini de Vigena)

1463, 1470

forniciaro of Alessandro

Bibl.Oliv. 937, vol.IV, Sq.S, c.39; ASPN, Matteoli, vol.3, 13 January 1470, page unnumbered

Battaglino da Rieti

1457

famigliare of Alessandro

Madiai, p.109 
Battista di Lello degli Almerici da Pesaro

1512

capitano of the port

Bibl.Oliv. 455, vol.I, c.534; Bibl.Oliv. 455, vol.II, c.137

\section{Battista de' Moregni di Mantova}

1490

cappellano of Maddalena Sforza dei Gonzaga in Pesaro

Bibl.Oliv. 376, vol.1I, c.567

Battista Pollato

1515

cameriere of Galeazzo Sforza

ASF, Urbino, Cl.III, Fa. 38, c.209

Benedetto Reguardati da Norcia

born c. 1398/99; 1453, 1457, 1458

doctor of Alessandro and Sveva; ministro and luogotenente of Alessandro; had the care of Battista during Alessandro's absence 145758

Feliciangeli, Sveva, p.12; idem., Battista, p.10

Benvenuto

died 1467

squadrero of Alessandro

Paltroni, p.225

Berardino Samperoli

1458

companion to Costanzo (brother of Mattea, Alessandro's mistress before Pacifica)

Feliciangeli, Battista, p.13

Don Bernabeo di Giovanni

\section{5}

soprastante of construction on Alessandro's palace

Bibl.Oliv. 937, vol.IV, Sq.S, c.14v; ASPN, Sepolcri, vol.2, c.235v

\section{Bernardino}

died 1510

fornaio di corte of Giovanni

Bibl.Oliv.455, vol.II, c.161; Cinelli, p.133

\section{Bernardino}

1515

servant of Galeazzo

ASF, Urbino, C1.III, Fa. 38, c.209
Ser Bernardino di Ser Gaspare Fattori 1503, 1512

procuratore for Galeazzo for the rendering of the Rocca Costanza; segretario of Galeazzo (also cancelliere of Pesaro)

Feliciangeli, Lettere, p.43 n.27

Bernardino Superchi

1497

tesoriere of Giovanni

Bibl.Oliv. 376, vol.IX, c.221

Bernardo detto Abbate dei Bossi del fu Pietro 1477

famigliare of Costanzo

Bibl.Oliv. 376, vol.II, c.455

Bernardo Monaldi

1503, 1504

segretario and medico of Giovanni; his agent in Venice

Feliciangeli, Lettere, p.42 n.21; idem., Lucrezia, p.43; Vaccai, Ginevra, p.168

Bertolda di Perugia

1457

donna di compagnia of Sveva

Madiai, p.108

Blaxio

1515

servant of Galeazzo

ASF, Urbino, C1.III, Fa.38, c.209

Camillo Leonardi

1500

doctor

Feliciangeli, Sull'acquisto, p.44

Camillo Samperoli

1512

ambassador sent to Rome by Galeazzo

Feliciangeli, Lettere, p.10

Carlo del q. messer Benedetto delli Reguardati da Norsia

1473

cavaliere of Costanzo

Bibl.Oliv. 937, vol.V, Sq.AB, c.13v 


\section{Carlo Sforza}

born c. $1461 ; 1475,1481$

siniscalco at Costanzo's wedding banquet

Tabarrini, p.14; ASPN, Sepolcri, vol.10, c.407v

Cesare Alberti

scalco of Giovanni

Vaccai, Ginevra, p.172

Mro Cherubino di Milano

$1476,1478,1479,1483,1491,1492$; died $1494 / 95$

muratore, muratoris ac etiam ingegnerii of Costanzo; given patent of ingegnere by Giovanni (1491); sopraintendente di tutti i lavori difortificazione, ponti, strade, chiuse, ecc., for Giovanni

ASPN, Sepolcri, vol.8, cc.162v, 242; vol.9, c.190; ASPN, Matteo Lepri, vol.10, c.138v; Bibl.Oliv. 384, c.229; ASPN, Sepolcri, vol.11, cc.137, 146; Vaccai, 1909, p.80; Bibl.Oliv. 376, vol.I, c.64; Feliciangeli, Sull'acquisto, p.58; Bibl.Oliv. 376, vol.I, cc. 258, 259v-260

Chiarelmo de Spoleto

1515

segretario of Galeazzo

ASF, Urbino, C1.III, Fa. 38, c.208v

Christoforo delli Perusini

1479,1481

luogotenente of Costanzo

ASPN, Matteo Lepri, vol.10, c.138v; Vaccai, 1928 , p.202

Domenico

1500

maestro di stalla of Galeazzo

Feliciangeli, Sull'acquisto, doc.VIII, p.83

Domenico di Barignano

$1474,1481,1490$

sent by Costanzo to the Patriarch of Aquilea to announce his forthcoming marriage; ambassador in Rome for Costanzo; procuratore for Giovanni

Bibl.Oliv. 455, vol.I, c.330; Bibl. Oliv. 376, vol.VI, cc.325, 325v-326, 332v-333

Ser Dominico

1468

cancelliere of Alessandro

Olivieri, Sforza, p.C

\section{Donato Stephano da Cotignola}

1500,1515

cameriere and sescalco of Galeazzo

Bibl.Oliv. 387, c.38v; Vernarecci, Libreria, p.523; ASF, Urbino, C1.III, Fa.38, c.208

Dulcius

1506

luogotenente of Giovanni

ASPN, Matteo Lepri, vol. 37, c.10; Domenico

Zucchella, vol. 39, c.107

Ercole Bentivoglio

born c. 1461; 1475, 1481

siniscalco at Costanzo's wedding banquet

Tabarrini, p.14; ASPN, Sepolcri, vol.10, c.407v

Ercole Sforza (illegitimate brother of Costanzo?) born c.1461; 1475

cavaliere

Tabarrini, p.13

Factorino Picinino

1458

one of the servants who had the care of Battista during Alessandro's absence in 1457-58

Feliciangeli, Battista, p.10

Federico

1476

cameriere of Costanzo

ASPN, Sepolcri, vol.8, c.156

Federico del fu Ser Gualtiero di Bartolomeo da S. Angelo in Vado

1485

siniscalco of Camilla and Giovanni

Bibl.Oliv. 376, vol.I, cc.383-85

Filippo de Neapoli

1476

depositario denariorum for construction of the Rocca Costanza

ASPN, Sepolcri, vol. 8, c.256

Fra Francesco d'Ancona

1466

confessor of Alessandro

Olivieri, Sforza, p.XC 
Francesco di Andrea delli Piccini da Todi $1464,1465,1467,1479,1480,1487$ referendario o revisore of Alessandro; vice podestd of Pesaro; giureconsulto and podestd of Pesaro; auditore of Giovanni

Bibl.Oliv. 937, vol.IV, Sq.T, cc.21v, 42; ASF, Urbino, Cl.I, Div.B, Fa.10, c.1042; Olivieri, Sforza, p.XCVI; Bibl.Oliv. 376, vol.II, c.461; ASPN, Germano Germani, vol.4, c.249v

Francesco di maestro Angelo 1458

scalco of Costanzo

Feliciangeli, Battista, p.13

Francesco Arduini

1512

ambassador sent to Rome to plead for Galeazzo

Feliciangeli, Lettere, p. 10

Francesco del fu (Orlandino ?) di Borgo S. Donnino

1491

curiale of Giovanni

Bibl.Oliv. 376, vol.VI, c.368v

Francesco di Bartolomeo da Crespolano 1482

servitore of Costanzo

Bibl.Oliv. 455, vol.I, cc.138-39

Francesco del q. Stefano Becci (Bezio) da Fiorenza

1473, 1486, 1493; died c.1510

a speziale (spice merchant) who became maggiordomo of Giovanni

Bibl.Oliv. 937, vol.V, Sq.AB, c.13v; Bibl.Oliv. 455, vol.I, c.371; Olivieri, Diplovatazio, p.XIV; Gregorovius, Appendix p.31, doc.9; Bibl.Oliv. 376, vol.I, c.327

Francesco delli Beni

\section{1}

referendario and revisore of Costanzo

Vaccai, 1928, p.202

Francesco di Bonadia de' Zanchis 1464

famigliare of Alessandro

Bibl.Oliv. 455, vol.II, c.103v
Francesco da Cotignola

1470, 1473

cassiero of Alessandro and Costanzo

Bibl.Oliv. 374, vol.I, c.106; Bibl.Oliv. 937, vol.V, Sq. AB, c. $13 \mathrm{v}$

Francesco di Gerolamo da Monte Milone, detto Milone

1491

staffiere and famigliare of Camilla

Bibl.Oliv. 376, vol.VI, c.362v

Francesco di Guglielmo Verità di Verona 1460-64

famulus familiaris, marescalchus of Alessandro

Soranzo, Cronaca sconosciuta, pp.96-97

Francesco del fu Orlandino di Borgo (same as Francesco di Borgo S. Donnino ?)

1492

connestabile for Giovanni

Bibl.Oliv. 376, vol.VI, c.385

Francesco da Palude (son of Niccold)

$1479,1480,1490-93,1494 / 95,1497$; died before 1501

siniscalco of Costanzo; oratore of Giovanni at Milan(1490-93); maestro di casa and maestro delle entrate of Giovanni $(1494 / 95,1497)$

Bibl.Oliv. 376, vol.II, c.462; Feliciangeli, $L u$ crezia, p.32 n.1; Bibl.Oliv. 376, vol.VI, cc.42324

Galeotto Agnesi da Napoli

after 1459; died 1462

segretario and luogotenente of Alessandro

Feliciangeli, Battista, p.13

Gaspare

1456

cappellano of Sveva

Oliviery, Sforza, p.L

Gaspar de Cesena

1458

servant of Battista

Feliciangeli, Battista, p.12 
Gasparino Ardizij (de Mediolana)

1465,1473

doctor of Alessandro (who marries him to his mistress, Pacifica); then doctor of Costanzo, and also for the town of Pesaro

Olivieri, Sforza, pp.XCV-XCVI; Bibl.Oliv. 937, vol.V, Sq.AB, c.13v

\section{Giacometto da Caiazzo}

1497

capitano dei balestrieri e sagitarri of Giovanni Bibl.Oliv. 376, vol.I, cc.389-90

Iacominus

1469

cameriere of Alessandro

Bibl.Oliv. 376, vol.X, c.149

Giacomo (Jacomino) (same as the above ?)

1497; died 1510

cameriere, cameriere maggiore of Giovanni

Feliciangeli, Lucrezia, p.43; Bibl. Oliv. 455, vol.II, c.161; cinelli, p. 133

Giacomino di Ferrara

died before April 1493

curiale of Giovanni

Bibl.Oliv. 376, vol.VI, c.406

Giacomo di Ancona

1491

curiale and famigliare of Giovanni

Bibl.Oliv. 376, vol.VI, c.374

Ser Jacomo delli Bagarotti da Piacenza (da Parma)

$1473,1475,1485$

cancelliere and segretario of Costanzo; segretario of Camilla and Giovanni

Bibl.Oliv. 937, vol.V, Sq.AB, c.13v; Ratti, p.155; Vaccai, Le nozze, p.35; Bibl.Oliv. 455, vol.II, c.11

Giacomo Biancuccio

1498; died 1510

depositario del porto and tesoriere for Giovanni

Bibl.Oliv. 455, vol.I, c.243; Bibl.Oliv. 455, vol.II, c.161; Cinelli, p.133

Mro Jacomo di Ser Guido da Verona 1463

scrittore, scrivano, segretario of Alessandro

Bibl.Oliv. 937, vol.IV, Sq.R, c.29v; Soranzo,

Cronaca sconosciuta, p.97
Mro Jacomo del q. Bartolomeo da Norsia

$1463,1464,1465,1468,1473$

ministro, fattore of Alessandro

Olivieri, Sforza, p.LXXI; Bibl.Oliv. 376, vol.VIII, cc.226-27; Bibl.Oliv. 937, vol.IV, Sq.R, c.43v; Sq.T, c.42; vol.V, Sq.Z, c.8v; Sq.AB,c.13v

Iacomo di Pero Banzo da Fossombrone 1440

castellano (with seven pages) of the Rocca of Pesaro

Olivieri, S. Tommaso, p.88

Giacomo da Pesaro

1430s-1450s

humanist and notary

Saviotti; Feliciangeli, Costanza, p.19 n.3

Jacomo Piccinino

1457

allevato of Alessandro

Feliciangeli, Sveva, p. 17

Giacomo Probo di Atria (de Probis d'Atri, son of Angelo ?)

1481

ambassador for Costanzo in Rome

Bibl.Oliv.376, vol.VI, cc.325, 325v-326

Mro Jacomo delli Scotti da Marignano

1458

barbiere of Alessandro

Bibl.Oliv. 937, vol.IV, Sq.Q, c.25v

Giacomo Venuti

1505

luogotenente of Giovanni

Bibl.Oliv. 455, vol.II, cc.260-61

Gian Antonio da Cremona

1491

credenziere of Giovanni

Bibl.Oliv. 376, vol.VI, c.385

Gian Francesco detto Riccio di maestro Tommaso (Bettini da Urbino) barbiere

1481,1482

cameriere of Costanzo

Bibl.Oliv. 376, vol.II, cc.467, 469 


\section{Gian Pietro del fu Mro Tomasso calzolaio 1471 \\ trombettiere of Alessandro \\ Bibl.Oliv. 376, vol.I, c.374}

\section{Gianozzo}

1478

castellano

Olivieri, Lettera, p. V

Ginevra

1515

servant of Galeazzo

ASF, Urbino, C1.III, Fa.38, c.209

Giorgio Attendolo da Cotignola 1500

castellano

Feliciangeli, Lettere, p.41 n.16;idem., Sull'acquisto, pp.39, 45, 46, 47

Giorgio Ayberti

scalco of Giovanni

Vernarecci, L'incendio, p.791

Giovanni Andrea da Gambarano

1515

auditore of Galeazzo

ASF, Urbino, C1.III, Fa.38, c.209

Giovanni di Antonio Guglielmini di Bellinzona 1491,1493

cameriere of Giovanni

Bibl.Oliv. 376, vol.VI, cc.384, 413v

Giovanni Antonio de Bresani da Cremona

\section{5}

cancelliere of Alessandro

Bibl.Oliv. 376, vol.X, cc.145v, 146; Bibl.Oliv. 937, v.IV, Sq.T, c.40; Olivieri, Sforza, p.LXX; Bibl.Oliv. 376, vol.VII, cc.81, 346-48

Giovanni Antonio del Tonso

1468

corriere of Alessandro

Olivieri, Sforza, p.CIII

Giovanni Battista dell'Antella 1457

computista of Alessandro

ASPN, Sepolcri, vol.1, c.145
Giovanni Battista de Narni

1467

cancelliere of Alessandro

Olivieri, Sforza, p.XCVII; Soranzo, Anonimo, p. 242 n.2

Giovanni Benevoli (Bonavoglia) da Mantova 1489-91

segretario of Giovanni

Feliciangeli, Sull'acquisto, p.56 n.3

Giovanni Germani

1490s, 1497

cancelliere of Giovanni; notaio of Pesaro; segretario del comune (1497)

Olivieri, Gradara, p.97; Feliciangeli, Lucrezia, p.67

Giovanni di Giontarello da Pesaro

c. 1451

famigliare

Olivieri, Sforza, p.XLV

Giovanni da Lacha (dal Lago)

1478

one of Costanzo's squadra

Bibl.Oliv. 376, vol.I, c.344

Giovanni Maria Dino da Castelfidardo

1496-1500

luogotenente of Giovanni

Feliciangeli, Sull'acquisto, p.53 n.2, p.57 n.1

Giovanni Ondedei

1499

capitano of Monte Baroccio

Bibl.Oliv. 455, vol.I, c.344

Giovanni di Padovani

1481

fattore of Costanzo; astrologer

ASPN, Sepolecri, vol.10, c.407v, Vaccai, 1909, pp. 84-85

Mro Giovanni di Pietro alias Riccio del fu Scaramuccia di Torricella parmense

1493

cuoco of Giovanni

Bibl.Oliv. 376, vol.VI, cc.411 v-12

Giovanni de Roxellis da Aretrio

1469

luogotenente of Pesaro for Alessandro

Olivieri, Sforza, p.CV 
Giulio di Piersante Bosi da Sarnano

1457

ministro of Alessandro

Madiai, p.109

Giustiniano Castelli da Cremona

c. 1463

luogotenente of Pesaro for Alessandro

Vaccai, 1909, p.43

Guglielmo da Pesaro

1444, c. 1463

ballerino, choreographer of dances at Alessandro's wedding; dedicated dance treatise to Galeazzo Maria Sforza of Milan

Rodocanachi, p.198; Pellegrin, pp.40-41

Guido Antonio da Sajano

born c. 1479; 1499

cameriere of Giovanni

Cinelli, p.93, and p.161 document

Hieronyma da Pesaro

1515

domicella of Ginevra Bentivoglio Sforza, wife of Galeazzo

ASF, Urbino, Cl.III, Fa.38, c.209

Hieronymo

1515

cameriere of Galeazzo

ASF, Urbino, Cl.III, Fa.38, c.209

Lanfranco de Corvis

1456-62

cancelliere of Alessandro

Olivieri, Sforza, pp.LXVI-LXVII; Bibl.Oliv.

374 , vol.I, cc.56-57

\section{Lelio dei Maddaleni Capodiferro}

1495

oratore of Giovanni at Rome

Feliciangeli, Lucrezia, pp.24, 40

Leonardo qm Giovanni Botta da Cremona

$1465,1467,1471$

cancelliere and segretario of Alessandro

Bibl.Oliv. 937, vol.IV, Sq.T, c.41v; Bibl.Oliv. 376, vol.X, c.146; Olivieri, Sforza, pp.XCV, CIX
Leonardo dal Colle

1480

copista of Costanzo

Vaccai, Le nozze, pp.28-29; Miniature, p.43 no.57

Lionino Giovanni di Bergamo

1492

armigero of Giovanni

Bibl.Oliv. 376, vol.VI, c. 392

Lorenzo de (...)

1515

cancelliere of Galeazzo

ASF, Urbino, Cl.III, Fa.38, c.209

\section{Lorenzo Lauti da Siena}

1495

segretario of Giovanni; consigliere and procuratore for Lucrezia Borgia

Feliciangeli, Lucrezia, pp.30, 31 n.3

Luciano da Laurana

1476, 1478, 1479

ingegnere of Costanzo

ASPN, Sepolcri, vol.8, c.242; vol.9, c.190; Matteo Lepri, vol.10, c.138v

Ludovico Bergolini da Bologna

1457

famigliare and commensale of Alessandro

Feliciangeli, Sveva, p.18; Madiai, p.97

Ludovico de Cardanis da Torricella di Parma 1493, 1497-1500, 1510; died 1510

cancelliere and segretario of Giovanni; drew up Giovanni's will (1510)

Gregorovius, p.31 document 9; Feliciangeli, Lucrezia, p.67; idem., Sull'acquisto, p.53 n.2; Bibl.Oliv. 455, vol.II, cc.161, 199v; Cinelli, p.133

Ludovico da Pexia

1452

castellano of the fortress of Pesaro

Olivieri, Zecca, p.212

Luigi di Bonabello da Salò

1500

sent by Giovanni to "ritirare certa quantità di perle lasciate dal padre Costanzo in deposito a Bonifacio Manerba di Brescia"

Feliciangeli, Sull'acquisto, p.41 
Maddalena del q. Petrozorzo de Almerici da Pesaro

1457-58

servant of Battista

Feliciangeli, Battista, p.9

\section{Marco Citara}

1494, 1497, 1498, 1503; died 1510

mercante who became referendario, maestro delle entrate and maestro di casa for Giovanni Bibl.Oliv. 376, vol.VI, c.411v; Feliciangeli, Sull'acquisto, p.53 n.2; ASPN, Giovanni Germani, vol.16, c.224; Bibl.Oliv.455, vol.II, c.161; Cinelli, p.133

\section{Marco de Monaldi}

$1458,1459,1465$

scalco of Alessandro; councillor, soprastante for construction on Alessandro's palace

Feliciangeli, Battista, p.10; Olivieri, Sforza, p.XLVIII; Bibl.Oliv. 937, vol.IV, Sq.S, c.14v; ASPN, Sepolcri, vol.2, c.235v

\section{Marcone del fu Giacomo}

1486, 1495

uomo d'arme of Giovanni (before 1495)

Bibl.Oliv. 376, vol.VI, c.415v

Margarita de li Ardoino da Pesaro

1457-58

servant of Battista

Feliciangeli, Battista, p.9

\section{Margherita da Marzano di Napoli}

1479

damigella of Camilla (married Francesco, son of Niccolo della Palude)

Feliciangeli, Lucrezia, p.32 n.1

\section{Mariano di Tassolo alias il Perusino \\ 1464}

lived in the palace with Costanzo; occupation not known

Bibl.Oliv. 937, vol.IV, Sq.T, c.18

\section{Marino Grisanti}

$1447-48$

rappresentante and procuratore of Alessandro, for the wedding between Alessandro and Sveva Feliciangeli, Sveva, p.9
Martino Filetico

1459

Roman humanist; teacher of Battista and Costanzo

Feliciangeli, Battista, p.6

Matteo di Antonio de Callio

1445

cappellano of Costanza Varano Sforza

Sajanello, p.375

Matteo del fu Giovanni di Salò

1494

connestabile of Pesaro

Bibl.Oliv. 376, vol.VI, c.413

Matteo da Sassoferrato dei Collenucci

1458; died 1465

grammar instructor to Battista and Costanzo; notaio and cancelliere

Feliciangeli, Battista, pp.6, 14

Ser Michele (is he identical with Ser Michele de Covardi, father of Vittoria, donzella of Costanza and Sveva ? See Olivieri, Appendice, p.V)

1458

cancelliere of Alessandro

Paltroni, p.115; Feliciangeli, Sveva, p.76

Michele de Vittorini

1478

worked for Costanzo

Bibl.Oliv.376, vol.VII, cc.98-99

Niccolò di Barignano

1467, 1473, 1474, 1475; died 1484 in Fano

famigliare of Alessandro; segretario and squadrero of Costanzo

Soranzo, Anonimo, p.243 n.1; Ratti, p.155; ASPN, Sepolcri, vol.7, c.150; Tabarrini, p.4; Bibl.Oliv. 455, vol.I, c.336

Nicolò Pacediano

segretario of Galeazzo

Ratti, p.172 n.10

Niccolò della Palude

1465,1474

luogotenente of Alessandro and Costanzo

Bibl.Oliv. 937, vol.IV, Sq.S, c.15; vol.V, Sq.AB, c. $14 \mathrm{v}$ 
Niccolò Pietro da Perugia (Nicolaus Petri de Perusio; Nicolò Perusino)

$1457,1475,1476,1478,1481$

famigliare of Alessandro; revisore of Costanzo

Feliciangeli, Sveva, p.80; Madiai, p.96; ASPN, Sepolcri, vol.8, cc.68, 256; vol.9, c.190; Vaccai, Le ville, p.265; idem., 1928, p.202

Niccolò Porcinari de Aquila

$1463 / 64$

luogotenente of Pesaro for Alessandro Olivieri, Sforza, pp.LXV, LXXX

Niccolò da Saiano

$1481,1491,1493,1500$

famigliare of Costanzo; vicario della gabella; commissario and consultore for Giovanni; orator et procurator ac specialis nuntius for the marriage between Giovanni and Lucrezia Borgia; oratore speciale sent to Venice

Bibl.Oliv. 455, vol.II, c.320v; Bibl.Oliv. 376, vol.VI, cc.372v-73; Gregorovius, Appendix p.31, doc.9; Feliciangeli, Sull'acquisto, pp.16, 43

Nicolo delli Savini da Santa Vittoria

$1464,1467,1468,1478$

podestà of Pesaro; dottore in diritto and auditore of Alessandro; luogotenente for Alessandro and Costanzo

Bibl.Oliv. 455, vol.II, c.120; Soranzo, Anonimo, p.243 n.1; Vaccai, 1928, p.202; Bibl.Oliv. 376, vol.II, c.457

Nobilia da Parma

c. 1457

donna di compagnia of Sveva

Madiai, p.109

Ser Orlandino di Ser Bartolino dei Superchi da Pesaro (da Tomba)

1447(48), 1458; died c.1471

cancelliere of the Malatesta and of Alessandro; drew up the marriage contract of Alessandro and Sveva

Feliciangeli, Sveva, p.9 n.1; idem., Battista, p. 10; Bibl. Oliv. 458

\section{Pandolfo Collenuccio}

\section{3}

humanist, ambassador of Giovanni and Camilla in Rome

Bibl.Oliv. 376, vol.VI, cc.328, 329
Pasquale Maripetro (Malipiero)

born c. $1447 ; 1458$

companion of Costanzo (cousin of the Doge of Venice)

Feliciangeli, Battista, p.13

Petro

1515

servant of Galeazzo

ASF, Urbino, Cl.III, Fa.38, c.209

Petro de (...) (not same as above)

1515

cameriere of Galeazzo

ASF, Urbino, Cl.III, Fa.38, c.208

Pier Giorgio Almerici

1440s, 1457; died c. 1468

famigliare of Elisabetta Malatesta Varano in Pesaro; famigliare and commensale of Alessandro

Feliciangeli, Elisabetta, p.201; Bibl.Oliv. 376, vol.IX, cc. 177,182

\section{Piergiorgio Almerici}

1512

ambassador in Rome for Galeazzo

Feliciangeli, Lettere, p.10

Piergiovanni di Alessandro da Camerino

1491

armigero of Giovanni

Bibl.Oliv. 376, vol.VI, c.374v

Piermatteo Giordani

1492, 1508, 1512

capitano of Novilara; Count Palatine; ambassador in Rome for Galeazzo

Bibl.Oliv. 376, vol.IX, cc.136, 80; Feliciangeli, Lettere, p.10

Piero da Cornazzano

1457

cameriere and scudiero of Alessandro

Feliciangeli, Sveva, p.23; Madiai, pp.94, 97

Piero Gentile di Varano (is he identical with Pier Gentile da Camerino, born c.1461, who carried the baldachin at the wedding of Costanzo and Camilla? Tabarrini, p.13)

c. 1503; died 1508

oratore of Giovanni in Venice

Vaccai, Ginevra, p.168; Feliciangeli, L'itinerario, p.34 n.2 


\section{Piero Lodovico Piemontese}

died 1456

cameriere of Alessandro (first husband of his mistress, Pacifica)

Feliciangeli, Sveva, p.15

Pier Ludovico Saraceni da Pesaro

1499

dottore and cavaliere; oratore straordinario sent to Venice by Giovanni

Feliciangeli, Sull'acquisto, pp.22, 23

Pier Sante di Marino Bosi da Sarnano

\section{5-58}

ministro of Alessandro

Feliciangeli, Battista, p.9

Pietro Barignani da Brescia

1503

canonico; procuratore for Giovanni to borrow money for the restitution of the Rocca Costanza

Feliciangeli, Lettere, p.41 n.20

Prospero Montani da Fermo

1491

luogotenente for Giovanni

Bibl.Oliv. 376, vol.VI, cc.360, $371 \mathrm{v}$

Raniero Almerici

born 1430,1458, 1468, 1475, 1484, 1498, died 1499/1501

nominated cavaliere aurato by Francesco Sforza; Count Palatine (1468); served Alessandro; capo di squadra for Costanzo; equitis serving Giovanni

Bibl.Oliv. 376, vol.IX, cc.177v-78; Feliciangeli, Costanza, p.39 n.2; Tabarrini, p.4; Bibl.Oliv. 376, vol.VI, c.426; ASPN, Giovanni Germani, vol.16, c.224

Riccio del fu Ambrogio di Milano 1493

famigliare and curiale of Giovanni

Bibl.Oliv. 376, vol.VI, c.409

\section{Roberto Ondedei}

$1464,1467,1468$

commisario for Alessandro; his luogotenente and segretario, and ministro in Venice

Bibl.Oliv. 376, vol.VIII, c.220; ASF, Urbino, Cl.I, Div. B, Fa.10, c.1042; Soranzo, Anonimo, p.242 n.2; Olivieri, Sforza, p.CII
Sebastiano Spandolini

1500,1503

famigliare of Giovanni

Feliciangeli, Sull'acquisto, p.41 n.3; Olivieri, Diplovatazio, p.IX

Mro Silvestro di Marco Sozzi dei Graziani da Cotignola

1476; died c. 1491

castellano of the fortress of Gradara

Bibl.Oliv. 376, vol.II, c.453; Bibl.Oliv. 376, vol.VI, c. 370

Simone da Pesaro

1462

depositario for Alessandro and for Pesaro

Olivieri, Sforza, p.LXVI

Spilimbertus Bartholomei de Crispolano

1476

famigliare of Costanzo

ASPN, Sepolcri, vol.8, c.242

Staxio q. Staxii de Cotignola

1473,1476

suprastantibus deputatis supra fabrica of the Rocca Costanza

Bibl.Oliv. 937, vol.v, Sq.AB, c.13v; ASPN, Sepolcri, vol.8, c. 242

\section{Sveva}

1457

damigella of Sveva Montefeltro Sforza

Feliciangeli, Sveva, p.35 n.2

Terenzio

died 1510

dispensiere for Giovanni

Bibl.Oliv. 455, vol.II, c.161; Cinelli, p.133

Thomasina

1515

servant of Galeazzo

ASF, Urbino, Cl.III, Fa.38, c.209

Thomasa

1499

cancelliere of Giovanni

Feliciangeli, Sull'acquisto, p.78 doc.III, p.79 doc.IV 


\section{Tommaso di Coldazzo}

1496

capitano generale of the contado of Pesaro

Bibl.Oliv. 376, vol.VI, c.422

Tommaso Diplovatazio

$1489,1492,1506$

called to Pesaro by Camilla in 1489 "per esercitarvi la carica di vicario delle appellazioni e gabelle;" avvocato fiscale della Camera for Giovanni; ambassador sent by Galeazzo to the Marquis and Cardinal of Mantua

Olivieri, Diplovatazio, pp.V, X, XI; Bibl.Oliv. 455, vol.I, c.372

Vittoria (daughter of Ser Michele de Covardi) died 1488

donzella of Costanza and Sveva (married to Count Monaldino di Montevecchio)

Olivieri, Sforza, p.LIII; idem., Appendice, p.IV

Zongus q. Jacobi Lodovici de Pisauro

1483

one of the suprastantibus of the Rocca Costanza ASPN, Sepolcri, vol.11, c.146 